\title{
(q) Creating an Outreach Plan that Accounts for the Seen and Unforeseen \\ EDITORIAL
}

\section{Zoe Bastone, University of Tennessee} Knoxville
(( There is no set standard for definining or planning outreach.》
$\mathrm{O}$ ver the last ten years, there has been a growing emphasis in the academic library literature on the role outreach plays in engaging users formally and informally throughout their collegiate experience. Many examples focus on initiatives that target specific groups of students: first-year students, transfer students, graduate students, and so forth. While there is wide agreement that outreach is a necessary component in an academic library's operations, there is a gap in the literature regarding how to create outreach programs that are efficient and effective and can account for unexpected additions to the outreach program. This article explores how outreach plans can create customized guidance for an academic library-first through a brief literature review and then through a case study about the process of creating and implementing an outreach plan at a subjectspecific academic branch library.

\section{Literature Review}

To create an outreach plan for my branch library, I started by scanning the literature to identify trends in how academic libraries initiate their process for designing outreach programs. In reviewing the literature, it became clear that there is no set standard for definining or planning outreach.

The question of how the profession defines outreach is long standing, with scholars debating whether it is even necessary to create an overarching definition. While one popular opinion simply states that academic librarians are likely to know outreach when they see it (Courtney 2008,4), it is important to note that the purview of outreach is likely to be different among libraries based on the mission of the institution that the library serves (4). Meanwhile, in the larger Library and Information Sciences field, there is a struggle to identify the key concepts that affect scholars' and practitioners' work. Fleming-May (2014) notes that defining key concepts such as outreach can "illuminate the theoretical foundations of a larger field of study" (204). While definitions of outreach may vary between academic libraries, there are commonalities in what constitutes outreach.

As part of my work to design an outreach plan, I crafted my own working definition that was shaped by Stephanie Diaz's conceptual analysis of outreach in academic librarianship. Diaz's definition is broad and applicable to a variety of academic library landscapes. It takes into account the library roles responsible for outreach, the outreach location, the program cadence (whether the outreach is a one-time event or part of a larger program), and the outreach goals (Diaz 2019, 191). (See Appendix for working definition.)

As noted, my review of the literature revealed wide variance in how academic libraries go about planning outreach programs. One survey 
conducted by the Association of Research Libraries notes that only 37 percent of libraries plan their outreach annually, with 38 percent of participants choosing combination tactics (LeMire, Graves, Farrell, and Mastel 2018). One recurring write-in response noted that academic libraries try to plan outreach annually while also accounting for unpredicted events (LeMire, Graves, Farrell, and Mastel 2018). Likewise, fostering a culture that is open to trying new tactics to reach library users is important. Owens and Bishop (2018) note that "A library that has a culture of yes understands that outreach creates positive associations with the library and encourages students to see the library as a partner in their success" (81). To embrace a culture of library outreach that is open to new ideas, academic libraries need to walk a fine line between preparedness and flexibility.

Sustaining an outreach program that is innovative and responsive requires formal plans. Many case studies of academic library outreach efforts focus on specific events or programs, but fail to explore how they contribute to a larger program. A resource that contributed significantly to my outreach plan was Wainwright and Mitola's (2019) paper, which focuses on the importance of creating outreach that is not only effective but also aligns with the strategic priorities of the university. Doing so secures greater buy-in from others within the library and helps in telling the larger story of how the library supports the institution.

One method for creating outreach plans that are aligned with the institution's strategic goals takes a curriculum-mapping approach. Curriculum mapping is a concept often used in planning instruction. In an outreach context, curriculum mapping has the potential to illuminate gaps and overlaps in an outreach program, which ensures that outreach is not only effective to a wide array of students but also efficient with the resources available (LeMire and Graves 2019).

Another method for strategic outreach planning emphasizes the role of assessment throughout the planning process. It includes establishing outcomes that will inform how the event aligns strategically to institutional goals. The outcomes can also act as a guide for selecting assessment methods that best fit the program or event. Depending on the scope of the outreach initiative and the staffing available, libraries will have varying levels of difficulties including assessment in their process. Farrell and Mastel (2016) note that a good way to determine which mode of assessment will work best for any outreach event is to first establish what information you want to know. Including mixed methods of assessment can help garner qualitative and quantitative feedback, making it easier to gauge the overall success of the program or event. (Farrell and Mastel 2016; German and LeMire 2018). While academic libraries may use that feedback to share their programming's overall impact with their institutions, assessment also serves as another data point that will help in planning future outreach initiatives.

\section{Case Study}

\section{About Pendergrass Library}

The University of Tennessee, Knoxville (UT) is a land-grant research university that supports 29,460 total students and 1,586 full-time instructional faculty (University of Tennessee n.d.). Three branches make up the UT Libraries system: the John C. Hodges library (the main campus library), the George F. Divine Music Library, and the Webster C. Pendergrass Agriculture and Veterinary Medicine Library. Situated about a mile from the main library and open to any UT affiliate, the Pendergrass Library primarily supports students in the Herbert College of Agriculture and the College of Veterinary Medicine. 
Pendergrass Library supports 7 percent of the student population at UT, ranging from undergraduates to doctoral candidates. In addition, Pendergrass Library supports the UT Institute of Agriculture's (UTIA) Extension and AgResearch programs, which serve communities throughout the state of Tennessee. Students at the agriculture and veterinary medicine schools frequently visit Pendergrass Library as it is the nearest study space available to students at their colleges.

\section{Rationale}

When I began my position as Pendergrass Library's only Outreach and Instruction Librarian, the fall semester was just set to begin. This did not leave much time to plan effective outreach, so the fall semester served as an opportunity to learn about the culture of outreach within Pendergrass Library and to identify potential areas of growth. While historically a hotspot for students of the nearby agriculture and veterinary medicine colleges, Pendergrass Library had difficulty in engaging students at events. Since Pendergrass's outreach is primarily targeted toward a small community of students, the desire to ensure the effectiveness of that outreach was heightened.

Reflections from the fall semester showcased how difficult it is to plan outreach on the fly. Because of limited staffing in the branch library, I was often planning events alone or in collaboration with one of the liaison librarians. Planning programs and events with limited staffing requires peak efficiency in planning. As I entered the spring 2019 semester, I was eager to explore new ideas for outreach programming. These outreach endeavors were unlike any program or event that Pendergrass had seen before, and I found that I had difficulty assessing their potential impact since they were disconnected from previous programming.

In May of 2019, I decided it was necessary to create an outreach plan for Pendergrass Library for the 2019-2020 academic year. After a year of observing the culture of outreach in my library, I wanted to create an outreach plan that was comprehensive in its scope, allowing time and space to reflect on whether and how a specific event or program supports the strategic priorities of the Libraries and the institution. Likewise, creating an outreach plan would provide an overview of the upcoming academic year's outreach calendar and enable us to see where there would be opportunities to add events, should they come up. While creating an outreach plan was initially used to help justify the purchase of promotional giveaways and a budget request for the upcoming year, this new outreach plan would end up doing so much more.

\section{Creating the Plan}

I began by consulting the literature to identify themes in other case studies. As noted in the literature review, a common theme that emerged was the push towards establishing outreach programs that are strategically aligned with the priorities of the institution. Working at an academic branch library added the need to consider the role that Pendergrass Library plays as a branch within the larger UT Library system. For example, Pendergrass Library has its own mission statement, which focuses on its role in supporting UTIA and programs that affect the state of Tennessee (Pendergrass Library n.d.). To ensure the outreach plan focused on the needs of Pendergrass and its communities, I developed the following framework for the outreach plan:

- Library mission statement

My outreach plan focused primarily on Pendergrass Library's mission statement so anyone reading the plan would understand the specific context 
in which it operates. For this reason, I placed the mission statement at the beginning of the plan.

- Goals of the outreach plan

Establishing goals for the plan helped ensure that there is intentionality behind the programs and initiatives being planned. The goals were broad enough to account for the opportunities that may arise later in the academic year, but also specific enough to accurately reflect the mission statement of the branch library.

- Definition of Outreach at Pendergrass Library

Using the learnings from my review of the literature as a guide, I created a definition that was customized to Pendergrass Library's work, and specific to the community that we serve.

- Events/programs

Here, I listed the events planned for the academic year, whether they were established programs or new events tenatively scheduled. As the academic year progressed, events that were not accounted for during the planning stage were added.

- Campus partnerships

At the end of the 2018-2019 academic year, I had met with campus partners from the Judith Anderson Herbert Writing Center, the Office of Information Technology, and Multicultural Student Life. Together we had set goals to attract students to the services they provided in Pendergrass Library.

- Promotional giveaway recommendations and inventory

This section included recommendations for promotional items the library would need to purchase and in what quantity. As the year progressed, this section was also used to inventory giveaways, which helped gauge needs for future giveaway purchases.

The largest section of the outreach plan was the detailed overview of each event and program that I intended to enact in the upcoming year. Working out the logistics for each event took the most time to develop. For each event I recorded the most critical details of the program or event, which I broke down into the following categories:

\section{- Strategic goals}

For this section I reviewed Pendergrass Library's annual goals, the UT Libraries strategic plan, the strategic plans for the Herbert College of Agriculture and the College of Veterinary Medicine, and "Vol Vision," UT's 2020 strategic plan. I pulled out any applicable goals from these plans to provide context for how my program or event support them.

- Description of the program or event

- Date and time of program or event

Here I listed potential dates for an event if I was unsure when it would take place. Throughout the year this section was updated when events were added or when dates were determined.

\section{- Outcomes}

In this section I recorded targeted outcomes for the program or event. At the completion of the program or event, I reviewed the targeted outcomes and added any additional outcomes that I discovered during implementation.

- Target audience

- Methods of marketing

Here I detailed any marketing work that would be needed to promote the program or event. This included social media content, graphic design, and the names of contacts who might assist in promoting the event. 
- Resources needed

This is where I inventoried the tools I would need to implement the program or event, including faculty and staff participation, resources already on hand (graphics, giveaways, etc.), and the resources that would need to be created. - Budget

I listed any budgetary needs for the program or event and I detailed what the funds would be used for.

- Time needed for planning and execution

This section was adjusted throughout the planning and implementation process. I provided an estimate of how much time was expected to be required for planning and implementing the program or event. Afterward, I reviewed this section and adjusted accordingly so that I would have a clear picture of what the time commitment would be if the program or event were to occur again.

- Methods of assessment

Here I recorded my plans for how to assess the program or event, whether my chosen assessment tool was formal (such as conducting a survey) or informal (such as reflecting on the interactions I had during the event).

- Giveaways utilized

For programs or events that would use promotional items, I estimated how many of each item I would need. After the event, I documented how many of each promotional item I used so as to aid in future planning.

\section{Implementing the Plan}

The process of creating and refining the initial outreach plan for the 2019-2020 academic year took three months to complete, from May to July of 2019. Throughout this process I approached members of my department to request their feedback and to establish buy-in. Though half of the members of the branch library do not have outreach-related responsibilities, sharing the plan launched larger conversations on different methods for reaching Pendergrass's users.

Throughout the fall 2019 semester, three new outreach events were added to the outreach plan. The first event had Pendergrass partnering with the other branches of the UT Library system in a Halloween library scavenger hunt. Students from every department on campus were encouraged to visit the different branches and to learn more about the resources available. Each library location had informational handouts, candy, and promotional giveaways. The other two events strengthened partnerships with the Herbert College of Agriculture's Student Life Coordinator. Historically, Pendergrass had difficulty engaging with its users at library-planned events. With this partnership, the library was able to gain a captive audience.

Unfortunately, a fourth event fell through at the planning stage due to communication barriers with departmental faculty and staff.

Continuing into the spring, more changes were made to the outreach plan as new partnerships within the UT Library system and the Herbert College of Agriculture developed. Often, my plan for an event or program served as an launching point for further discussions and relationship building. As changes were made to the outreach schedule, the plan was updated to reflect these new partnerships.

As noted in the plan framework, throughout the fall and spring semester I returned to the outreach plan to track the use of promotional giveaways. Before an event, I would set aside a designated supply of promotional giveaways. Often, it was more than what the event actually required, but having a predetermined supply made the process of tracking the use of giveaways easier 
since inventory was controlled. At the conclusion of the 2019-2020 academic year, I plan to review the remaining inventory to determine what needs to be purchased for the 2020-2021 academic year.

\section{Lessons Learned}

In reflecting on the process of creating and implementing Pendergrass Library's 2019-2020 outreach plan, the first lesson I learned was that an outreach plan should not be a static document. As the year progressed, the plan was used to aid in decision-making when we were considering whether to take on the responsibility of a new program or event. As well, I edited and made notes in the plan throughout the year when additional resources or ideas were incorporated. Creating a living document allowed room for creativity when last-minute changes need to be made to the event or program.

Because the implementation of the outreach plan was iterative, I realized that the process of measuring the final outcomes is not fully possible until the event or program is complete. Additional outcomes can be discovered throughout the process of planning an event or program.

For example, as part of Pendergrass Library's Date-with-a-Book program, students were encouraged to explore the library's leisure-reading collection. I expected that students would become more avid readers of the collection; what I didn't expect was that students would become more familiar with library staff because of this process. Students noticed when books that were part of the Date-with-a-Book program were put out on display. Throughout the program, students approached staff for recommendations based on the available genres. In addition, students would talk at length about their recent reads with library staff when returning books to circulation.

As I prepare for the 2020-2021 academic year, I remind myself of the most important lesson I learned from this experience: expect the unexpected. Even with events that happen every semester, new challenges and opportunities arise that change how students interact with the library and the role that the library plays in student success. Looking forward, I will now place a greater emphasis on thinking critically to plan events and programs that are more inclusive of students who are unable to participate in events on campus. Reviewing the 2019-2020 outreach plan serves as a baseline to consider new routes to reaching students, though the roadmap is ever changing.

\section{Conclusion}

The process of creating and implementing an outreach plan demonstrated how flexible one must be to create meaningful and efficient outreach. Outreach plans that allow for flexibility successfully straddle the seen and unforeseen, creating a customizable guide to their unique outreach landscapes. They enable outreach librarians to ensure their library's programs align strategically with their institution's priorities while also having a clear and positve impact on the faculty, staff, and students they serve.

\section{References}

Courtney, Nancy. 2009. "Breaking Out of Our Shell: Expanding the Definition of Outreach in Academic Libraries." In Academic Library Outreach: Beyond Campus Walls, edited by Nancy Courtney, 1-6. Westport, Connecticut:

Libraries Unlimited. 
Diaz, Stephanie A. 2019. “Outreach in Academic Librarianship: A Concept Analysis and Definition." The Journal of Academic Librarianship 45, no.

3: $\quad$ 184-194. https://doi.org/10.1016/j.acalib.2019.02.012.

Farrell, Shannon L., and Kirsten Mastel. 2016. "Considering Outreach Assessment: Strategies, Sample Scenarios, and a Call to Action." In the Library with the Lead Pipe. May 4, 2016.

http://www.inthelibrarywiththeleadpipe.org/2016/considering-outreachassessment-strategies-sample-scenarios-and-a-call-to-action/.

Fleming-May, Rachel A. 2014. "Concept Analysis for Library and Information Science: Exploring Usage." Library \& Information Science Research 36, no. 3-4: 203-210. https://doi.org/10.1016/j.lisr.2014.05.001

German, Elizabeth and Sarah LeMire. 2018. "Sharing the Value and Impact of Outreach: Taking a Multifaceted Approach to Outreach Assessment." Journal of Academic Librarianship 44, no. 1: 66-74. https://doi.org/10.1016/j.acalib.2017.11.001.

LeMire, Sarah and Stephanie J. Graves. 2019. “Mapping Out a Strategy: Curriculum Mapping Applied to Outreach and Instruction Programs." College \& Research Libraries 80, no. 2: 273-288. https://doi.org/10.5860/crl.80.2.273.

LeMire, Sarah, Stephanie J. Graves, Shannon L. Farrell, and Kristen L. Mastel. 2018. SPEC Kit 361: Outreach and Engagement. Association of Research Libraries. November 2018. https:/ / doi.org/10.29242/spec.361.

Owens, Tammi M. and Katie Bishop. 2018. “'Let's Try It!': Library Outreach in a Culture of Yes." Public Services Quarterly 14, no. 1: 75-82. https://doi.org/10.1080/15228959.2017.1411861.

Pendergrass Library. n.d “Mission and Values" Accessed May 8, 2020. https://www.lib.utk.edu/agvet/mission/.

University of Tennessee. n.d. “Quick Facts” Accessed May 8, 2020. https://www.utk.edu/aboutut/numbers/.

Wainwright, Amy, and Rosan Mitola. 2019. "Creating an Outreach Story: Assessment Results, Strategic Planning, and Reflection." Paper presented at the Association of College and Research Libraries Conference (ACRL), Cleveland, Ohio, 2019. http://www.ala.org/acrl/sites/ala.org.acrl/files/ content/conferences/confsandpreconfs/2019/CreatinganOutreachStory. pdf

\section{Author Details}

Zoe Bastone, Assistant Librarian for Outreach and Instruction, University of Tennessee Knoxville: zbastone@utk.edu.

\section{Appendix}

\section{Outreach plan 2019-2020}

\section{Mission:}

This outreach plan supports Pendergrass Agriculture and Veterinary Medicine Library in its mission to serve those seeking information and scholarship in areas important to the University of Tennessee's Institute of Agriculture (UTIA), which encompasses the Herbert College of Agriculture, the College of Veterinary Medicine, Ag Research, and UT Extension. The plan strives to connect current and potential users of Pendergrass Library to the highest quality of resources and to ensure equitable access to all information and resources within our collection. 


\section{Goals:}

- Develop Pendergrass's identity as a resource for the College of Veterinary Medicine (CVM) and the Herbert College of Agriculture (HCA) faculty, staff, and students through specialized events that promote our campus partners and Pendergrass's services and resources.

- Establish a culture of consistent feedback from the UTIA community through targeted outreach, surveys, and focus groups.

- Support niche groups such as first-generation students, graduate students, and transfer students.

\section{Definition of outreach}

Outreach consists of activities that connect Pendergrass Library with the UTIA community: Herbert College of Agriculture, College of Veterinary Medicine, Ag Research, and UT Extension. Outreach promotes awareness of Pendergrass's services, collections, spaces, technologies, etc. It includes giving the UTIA community the information, training, and knowledge to help them with their research, teaching, and learning goals.

\section{A listing of outreach events is found below.}

- Tentatively scheduled items are in bold

- Proposed times/items are in italics

1. Orientations for incoming students (Freshmen and transfer students)

- Strategic goals

o From UT Libraries' strategic plan: Teaching, learning and innovation

- Collaborate with campus academic support units to identify and provide targeted orientation and outreach for at-risk populations such as transfer students, first-year students, and others.

- Align Libraries and campus efforts to develop a strategy for helping transfer students build foundational skills to be successful at the university.

o From Pendergrass Library's 2017-2018 annual plan: Teaching, learning and innovation

- Provide inviting and inspiring spaces for learning, research, and engagement.

- Promote Pendergrass's spaces, services, and resources across UTIA.

o From UT Libraries' strategic plan: Sharing our story

- Increase awareness of library services and resources

- Use messaging appropriate to audiences at hand to increase knowledge about the Libraries' collections.

- Description of the event: Over the summer, incoming students for the fall 2019 semester come to campus and prepare for their first semester. Students will visit HCA and learn about the resources available to them on this side of campus, including Pendergrass Library.

- When:

o Freshmen orientation dates (1:15-1:45): May 30, June 3, June 5, June 10, June 13, June 17, June 20, June 24, June 27, July 1, July 8, July 11, July 15

o Transfer student orientations: May 29, June 12, July 3, July 17, August 14, August 15

- Outcomes: Incoming students will be introduced to Pendergrass Library's services and resources. Students will identify Pendergrass as a space they can utilize while at UT. 
- Target audience: Incoming HCA freshmen and transfer students

- Methods of marketing: Work with the Student Success Advisors to let them know the library has interest in contributing Pendergrass content to freshmen orientation.

- Resources needed: Slides with Pendergrass content

- Budget: $\$ 0$

- Time needed for planning and execution: 25 hours

- Methods of assessment: After each orientation, the Assistant Librarian will reflect on the sessions and what was interesting to the new students.

2. Syllabus Support Day (new event, added June 2019)

- Strategic plan goals

o From Pendergrass annual plan 2017-2018: Teaching, learning and innovation

- Provide inviting and inspiring spaces for learning, research, and engagement.

- Promote Pendergrass spaces, services, and resources across UTIA.

- Equip students, faculty, and staff with the knowledge and skills they need for academic success.

- Description of the event: This will be a targeted event for faculty and staff who teach writing courses, research-intensive courses, and other general education agriculture classes. This event will host the Writing Center, the Office of Information Technology andStudent Disability Services to showcase Pendergrass Library's services and demonstrate how these services support their students. This event will also showcase how instructors can integrate library resources and services into their syllabi/classes.

- When: August 7, 2019 from 1:00 to 3:00 p.m. (two weeks before the fall semester begins)

- Outcomes: Faculty will become acquainted with services and resources available to their students and how these services can support their teaching.

- Targeted audience: Herbert College of Agriculture instructors

- Methods of marketing: A survey will be created that asks instructors what they would like from this event. This survey will go out in June. In July we will send out an invitation requesting attendees RSVP so we can get an accurate headcount to inform our food order for the event.

- Resources needed: Survey design, catering, swag bag (old totes), stress cows, cell phone wallets, pens, highlighters if they have arrived, and flyers that instructors can take with them.

- Budget: \$385 for catering from Jason's Deli. Gallons of coffee to be delivered in the morning. At lunch attendees will receive boxed lunches. Gallons of tea and lemonade will also be delivered.

- Time needed for planning and execution: 35 hours

- Methods of assessment: Track attendees and whether they reach out to the library for library instruction. Document feedback from attendees and campus partners throughout the event.

\section{Make Breaks}

- Strategic plan goals

o From UT Libraries' strategic plan: Teaching Learning and Innovation -Equip students, faculty, and staff with the knowledge and skills they need for academic success. 
-Provide instruction and consultations on topics central to our mission, such as information literacy, poster design and printing, 3D design and printing, and academic writing.

- Description of the event: Make Breaks are an opportunity for faculty, staff, and students to learn about things they can make at Pendergrass using our 3D printers. Participants will learn the ins and outs of 3D printing, from finding a design they would like to print, to developing their own design.

- When: Second Thursday of the month from 1:00 to 3:00 p.m.

- Outcomes: Showcase to library users how to use a 3D printer. Faculty and staff will learn how they can incorporate 3D printing into their curricula.

- Target audience: Faculty, staff, and students from UTIA and the main UT campuses

- Methods of marketing: Social media stories, 3D printing news stories, calendar.utk.edu, UTIA listserv, Herbert Student News, 3D printing token pieces with customized messages to departmental faculty and staff.

- Resources needed: Signage that we can put up in the makerspace when a Make Break is happening. To assist with the marketing of the event, we will need to learn what questions patrons have regarding 3D printing. Common questions that are asked can inform how to market this event effectively to patrons. Collaborate with the Libraries Marketing department to identify how we can utilize our social media presence to promote the event. To provide targeted advertising to departments in HCA and CVM, craft a letter that to the department heads in the two colleges providing information about the event and asking that they share details with their departments. (3D printed Power Ts were created and sent out to eight departments.)

- Budget: $\$ 0.20$ cents per orange and white Power T. Thus far, we have given $\$ 1.60$ worth of Power Ts away to department heads.

- Time needed for planning and execution: 20 hours for the academic year

- Methods of assessment: Tracked attendance through the reservation process. After the event, Pendergrass's Assistant Library and IT Specialist will reflect on each Make Break and the conversations that arose during the events.

\section{Student Engagement carnival (added August 2019)}

- Strategic plan goals

o From UTK's Vol Vision: Undergraduate Education

-Engage Students in the Volunteer Experience

- Description of the event: This is an event to promote student engagement in student organizations in the HCA. Attendees of the event can circulate through the Brehm Animal Science building arena and learn about the different student organization. Pendergrass Library will be represented at the event, and we will be sharing handouts and resources that may be of interest to student organizations.

- When: September 4, from 6:00 p.m. to 9:30 p.m.

- Outcomes: Students will learn about how the library can provide targeted resources that will benefit the student organizations' academic and social goals.

- Targeted audience: Herbert College of Agriculture students

- Methods of marketing: We will not need to create any marketing materials.

Reach out to HCA's Coordinator for Student Life and Diversity to identify how we can help advertise.

- Resources needed: Plan to bring the following quantities of swag:

o 100 stress cows

o 100 cell phone wallets

o 250 pens

o 30 highlighters 
o 30 sporks

- Budget needed: $\$ 0$

- Time needed for planning and execution: 10 hours

- Assessment: Reflection

We had 160 attendees visit our booth last night. Originally, people come to the table to check out the "Wheel of Swag," but this served as an entry point for ZB to talk with students about the resources and services available to them as students and as potential leaders in student organizations. Because this event took place near the beginning of the semester, there were new students who discovered Pendergrass at this event.

- Swag given away:

o 45 stress cows

o 35 pens

o 17 sporks

o 19 cell phone wallets

o 23 hand sanitizers

o 21 highlighters

- Handouts given away:

o 15 3D printing brochures

o 30 Moo cards/ business cards

o 15 poster printing brochures

o 48 student organization/library resources handouts

\section{Ag Day}

- Strategic plan goals:

o From UT Libraries' strategic plan: Sharing Our Story

- Increase awareness of library services and resources

- Use messaging appropriate to the audience at hand to increase knowledge about the Libraries' collections.

- Description of the event: Ag Day is held every year and is a time for UTIA faculty, staff, students, alumni, and the general public to learn about the achievements of our colleges, research units, and Extension during the year as well as UTIA's plans to help improve the lives of all Tennesseans. Pendergrass will host a table that shows how we support the UTIA campus.

- When: October 5, 2019 from 2:30 p.m. to 5:30 p.m.

- Outcomes: Increase awareness to the UTIA community (faculty, staff, students, alumni, Extension, Ag Research, and friends and family) of how we support UTIA.

- Targeted audience: UTIA community, alumni, and other Tennesseans

- Methods of marketing: None

- Resources needed: Swag (we had 321 visitors last fall): pens, sporks, highlighters (Friday event only), hand sanitizer (Saturday event only), cell phone wallets (both days), standing banners

- Budget needed: $\$ 0$

- Time needed for planning and execution: 10 hours

- Potential assessment: Head count

- Swag given away:

o 130 hand sanitizers

o 150 (estimated) cell phone wallets (from 2018-2019 AY)

o 324 sporks

o 69 highlighters

o 133 pens

- Handouts given away:

o 14 Finding Extension publications 
o 15 Project Ceres

o 9 LinkedIn Learning (Friday only)

o 1 Library Society brochure

\section{Plant Sciences Poster Competition Poster Workshops (Did not happen; return to in} 2020)

- Strategic Plan goals

o From UT Libraries' strategic plan: Teaching, Learning and Innovation

- Goal: Equip students, faculty, and staff with the knowledge and skills the need for academic success.

-Provide instruction and consultations on topic central to our mission, such as information literacy, poster design and printing, 3D design and printing, academic writing, etc.

- Be a campus leader in furthering graduate student success.

- Offer instruction and support, at the point of need, by providing consultation and online learning materials to assist graduate students with their research and writing needs.

- Description: Students will learn about the best practices of creating a research poster. This workshop walks students through the logistics of how to utilize the UT template, how to use PowerPoint when creating a research poster, how to work with fonts and image sizes, and how to submit a poster request to either Pendergrass or the Studio. Tentatively, there will be two workshops that cover 1) the basics of poster design and 2) more specialized work with posters. Participants can choose whether to enroll in one or both workshops.

- When: To be determined

- Outcomes: Students will learn the logistics and best practices for creating a research poster. Students will learn how to submit a poster request to Pendergrass.

- Targeted audience: Graduate students in the plant sciences department.

- Methods of marketing: Post flyers on bulletin boards through the Plant Science buildings (Ellington and Plant Biotech); collaborate with the Plant Sciences Communications Specialist promote on social media

- Resources needed: Location to be determined. Check with Plant Sciences department about any requirements the participants must follow. Create a curriculum and PowerPoint. Note: a new Large Format Printing form is being created and will need to be incorporated into this work.

- Budget: $\$ 0$

- Time needed for planning and execution: 20 hours

- Potential assessment: Post-event survey that asks students what they learned. If participants enroll via workshop.utk.edu, a survey will go out automatically after the workshop. Raffle off a swag bag for participants.

\section{Halloween Quest (Added October 2019)}

- Strategic plan goals

o From UT Libraries' strategic plan: Sharing our story

-Increase awareness of library services and resources

- Description: This is a student-led initiative in which students will visit the different library locations, learn about the specific resources available to them, and receive swag (library trick or treating).

- When: October 31, 2019 from 11:00 a.m. to 1:00 p.m.

- Outcomes: Students will become acquainted with the resources and services found at the different branches of UTK Libraries.

- Targeted audience: Students from UT and UTIA

- Methods of marketing: Social media 
- Resources needed: When students visit each library location they will hear a library staff member provide a brief statement about Pendergrass. Prepared statement: At Pendergrass, you can find additional technology for equipment checkout, poster and 3D printing, and a variety of writing services at the Writing Center. Handouts for large format printing and 3D printing will be available for students.

- Budget: No additional funds are needed.

- Time needed for planning and execution: 5 hours; Allison Shepard is the main planner

- Methods of assessment: Keep a tally of the number of people who stop by the table

- Swag given away

o 25 cell phone wallets (from 2018-2019 AY)

o 25 stress cows

o 25 highlighters

- Handouts given away

o 3D printing brochure

o LFP brochure

\section{Date with a Book}

- Strategic plan goals

o From UT Libraries' strategic plan: Sharing our story

-Increase awareness of library services and resources

- Use messaging appropriate to the audience at hand to increase knowledge about the Libraries' collections.

- Description: To promote the leisure-reading collection, the month of February will be dedicated to Date with a Book. In Date with a Book, I will choose twenty books of different genres. This year, Hodges Library will also pick books to circulate.We will choose books that were purchased in the last four years and have had lower circulation stats. Pendergrass Library has an account on Goodreads.com that will be used to check ratings of potential books involved in the program. These books will be wrapped in brown paper and will have a short description. Students will be able to check out their "blind date" and read.

- When: Month of February

- Outcomes: Faculty, staff, and students will explore our leisure-reading collection.

- Targeted audience: UTK/UTIA community

- Methods of marketing: Collaborate with Learning Commons Librarian in charge of the Hodges' leisure-reading collection to develop a social media campaign. We will create digital signage that will be displayed in Pendergrass and Hodges.

- Resources needed: I will need to choose twenty books for Pendergrass and create short descriptions for them. A spreadsheet that provides information regarding the books' titles, authors, call numbers, and barcodes will be created so student workers can assist in keeping track of what books are checked out. This will also assist in determining which books should be included in future leisure-reading promotions.

- Budget: \$10 for brown wrapping paper.

- Time needed for planning and execution: 10 hours

- Methods of assessment: Formal mehods of assessment include reviewing the citculation statistics for the books that are checked out. In addition, I will review the genres of the books that were checked out during this time to see if there if a particular genre that saw the most circulation. I will gain informal feedback 
by talking with students when they return books to see what they thought of their choice.

\section{EUReCA poster workshops}

- Strategic Plan goals

o From UT Libraries' strategic plan: Teaching, Learning and Innovation

- Goal: Equip students, faculty, and staff with the knowledge and skills the need for academic success.

- Provide instruction and consultations on topic central to our mission, such as information literacy, poster design and printing, 3D design and printing, academic writing, etc.

- Description: Students will learn the best practices for creating a research poster. This workshop walks students through the logistics of how to utilize the UT template, how to use PowerPoint when creating a research poster, how to work with fonts and image sizes, and how to submit a large format poster print request to either Pendergrass or the Studio.

- When: In collaboration with the Director of Advising/Head of Undergraduate Research in Herbert College of Agriculture, we aimed to host the event on March 24, 2020, from 12-1:30, which was the Tuesday after spring break. Because of the COVID-19 pandemic, this event was cancelled, but the prepared presentation was recorded for those enrolled in the EUReCA poster competition.

- Outcomes: Students will learn the logistics of creating a poster. Students will learn how to submit a poster request to Pendergrass or the Studio.

- Targeted audience: Herbert College of Agriculture undergraduate students, Herbert honors students

- Methods of marketing: Social media, Herbert student news, bulletin boards, student success advisors, and other faculty (undergraduate coordinators?)

- Resources needed: Room reservation in one of the HCA buildings. Flyers will need to be distributed, and the workshop.utk.edu portal will need to be activated.

- Budget: $\$ 0$

- Time needed for planning and execution: 16 hours

- Potential assessment: Because this event was cancelled, a survey was sent out to the HCA students who participated in the virtual poster competition. This survey asked whether students watched the recording of the presentation and what other academic resources they used to create their poster.

\section{De-Stress for Success}

- Strategic plan goals

o De-Stress supports VolVision's goals for undergraduate education. The goals for undergrads include strengthening retention rates and providing high quality health, wellness, and safety programs and services.

o For graduate students

- From UT Libraries' strategic plan: Teaching learning and Innovation - Goal 1.3. Be a campus leader in furthering graduate student success

- Description: De-Stress for Success occurs once every semester during final exams to promote mindfulness and wellness to our students. Pendergrass hosts massage therapists, HABIT dogs, arts and crafts, games, and technologyrelated events. In spring 2020, due to the COVID-19 pandemic, a research guide to promote wellness and stress relief was created and shared on the UT Libraries' social media channels. 
- When: During final exams for fall and spring semesters; however, it was cancelled in the spring semester due to the COVID-19 pandemic.

- Outcomes: Students will be supported through activities and events that will relieve stress.

- Targeted audience: All UT students

- Methods of marketing: Herbert Student News, digital signs, social media, commons.utk.edu, calendar.utk.edu

- Resources needed: Set out the coloring sheets, origami paper, phone-polaroid paper, 3D printer pen, and board games.

- Budget: \$500 for food and \$150 for coffee (paid for with separate budget)

- Time needed for planning and execution: 15 hours

- Potential assessment: De-Stress for Success planning committee's survey, review responses to questions written on white boards throughout the library asking students how they are feeling, review comments from the comment book that is by the snack table.

\section{Pop-Up Library}

- Strategic Plan goals

o From UT Libraries' strategic plan: Sharing Our Story

-Increase Awareness of library services and resources

- Description: The Pop-Up Library is an initiative where either the library's graduate assistant or the Outreach and Instruction librarian will set up a table at selected locations aroumd the UTIA campus to promote library resources and services. In the most recent iteration of the Pop-Up Library, we are looking to make the program more opportunistic by setting up during crucial points in the academic year (beginning of fall and spring semester, midterms, and finals). We are also looking to use the Pop-Up Library in more UTIA events.

- When: Key points in the semester and during important events happening in the Herbert College of Agriculture.

- Outcomes: Faculty, staff, and students will learn about the library and its resources.

- Targeted Audience: Faculty, staff, and students in the Herbert College of Agriculture

- Methods of Marketing: Social media through the Libraries and collaborating with departmental social media to increase awareness.

- Resources Needed: Laptop or iPad; 3D printed models; flyers for 3D printing and poster printing; and the "Resources for Undergraduates," "Resources for Graduate Students," and "Resources for Faculty" handouts.

- Budget: $\$ 0$

- Time needed for planning and execution: 4 to 8 hours during the high-impact weeks, as needed for events. 20 to 40 minutes for setup and takedown.

- Potential assessment: The graduate assistant has a Google form on which to note the nature of interactions and status of the people they talk to (faculty, staff, student).

- Amount of Swag used

o August 2019

-Stress Cows: 41

- Cell phone wallets: 7

- Pens: 7

o September 2019

- Stress cows: 42

- Cell phone wallets: 9
- Sporks: 28

- Stickers: 5

- Pens: 19

o October 2019

- Stress cows: 9

- Cell phone wallets: 4

- Sporks: 7

- Stickers: 1 
o November 2019

- Stress cows: 24

- Cell phone wallets: 1

- Sporks: 17

- Stickers: 4

- Pens: 5

o December 2019: Pop-Up Library did not occur during December because of final exams.

o January 2020

- Stress cows: 0

- Cell phone wallets: 3

- Sporks: 7

- Stickers: 5

- Pens: 7

- Hand sanitizer: 5 o February 2020

- Stress cows: 0

- Cell phone wallets: 3

- Sporks: 7

- Stickers: 0

- Pens: 3

- Hand sanitizer: 4

o Pop-Up Library did not occur from March-May due to the COVID-19 pandemic.

\section{Campus Partnerships}

\section{Writing Center}

Goals:

1. Continue to build clientele of students in the Herbert College of Agriculture and College of Veterinary Medicine.

2. Utilize Thesis and Dissertation service to build clientele of graduate students from across UTIA/UT campuses.

- Methods of advertising: Showcase the new UT map feature on social media. The syllabus event in early August will promote the Writing Center to teaching faculty and staff.

- Opportunities: Herbert College of Agriculture will be reviewing their curricula soon, as part of creating a new strategic plan. Once we know the outcomes and goals of the new curricula and strategic plan, we will have new ways of supporting Herbert College of Agriculture.

- Hours for fall: 12:00-3:00 p.m. Monday through Friday.

\section{Subject Tutoring}

Goals:

1. Increase clientele of undergraduates from the different Herbert College of Agriculture departments.

2. Establish best methods of promoting Multicultural Student Life's (MSL) tutoring services.

- Methods of advertising: The Syllabus Support Day in early August provides an opportunity to connect faculty with this service. Once MSL has a list of courses available, this information will be sent to the Student Success Advisors in the Herbert College of Agriculture, and the members of the Herbert College of Agriculture social media task force.

- Opportunities: MSL will be hiring new tutors, which could allow a wider reach into the Herbert College of Agriculture student population as the tutors will themselves be HCA students. These tutors will be be able to provide support in classes that most HCA majors need to complete.

- Hours for fall: 5:00-8:00 p.m. on Wednesdays and 3:00-6:00 p.m. on Sundays

- Swag proposal: o Sporks

- Quantity: 1000 
- Price range $\$ 400-\$ 450$

o Stress cows/animals

- Quantity: 250

- Price range: $\$ 300-\$ 400$

o Hand Sanitizer:

- Quantity: 400

- Price range: \$400-\$500 o Highlighters:

- Quantity: 500

- Price range: $\$ 400-\$ 500$

o Pens:

- Quantity: 3000

- Price range: \$800-\$900

Total: $\$ 2850$ + shipping

\begin{tabular}{|c|c|}
\hline Resource & Cost \\
\hline Swag & $\$ 2850+$ shipping \\
\hline Yard Signs & $\$ 100-\$ 200$ \\
\hline Arts and crafts materials & $\$ 10$ \\
\hline Catering & $\$ 385$ \\
\hline & \$3345-\$3355 + shipping \\
\hline
\end{tabular}

Budget

\begin{tabular}{|c|c|}
\hline Items (beginning inventory) & $\begin{array}{l}\text { Quantity: Number of each item given away } \\
\text { at a specific event }\end{array}$ \\
\hline Sporks $(1000)$ & $\begin{array}{l}\text { CarnivOL: } 17 \\
\text { Ag Day: } 324 \\
\text { Henton Conference: } 32 \\
\text { VOLiday: } 45 \\
\text { Pop Up: } 66 \\
\text { Total: } 484 \text { given away at promotional } \\
\text { events }\end{array}$ \\
\hline Cows $(250)+80$ from $2018-2019 \mathrm{AY}$ & $\begin{array}{l}\text { CarniVOL: } 45 \\
\text { Halloween Quest: } 25 \\
\text { Pop Up: } 116 \text { (as of Dec 2019) } \\
\text { Clue: } 21 \\
\text { De-Stress for Success (Fall 2019): } 58 \\
\text { Total: } 54 \text { given away at promotional events }\end{array}$ \\
\hline Pens $(3000)$ & $\begin{array}{l}\text { CarniVOL: } 35 \\
\text { Ag Day: } 133 \\
\text { Henton: } 50 \\
\text { Pop Up: } 47 \\
\text { Total: } 265 \text { given away at promotional } \\
\text { events }\end{array}$ \\
\hline Highlighters (300) & $\begin{array}{l}\text { CarnivOL: } 21 \\
\text { vOLiday: } 50 \\
\text { Ag Day: } 69 \\
\text { Total: } 130 \text { given away at promotional } \\
\text { events }\end{array}$ \\
\hline Hand sanitizer ( 400$)$ & $\begin{array}{l}\text { CarnivOL: } 23 \\
\text { Ag Day: } 130 \\
\text { VOLiday: } 50 \\
\text { Total: } 205 \text { given away at promotional } \\
\text { events }\end{array}$ \\
\hline Cell Phone Wallet (270) & $\begin{array}{l}\text { CarniVOL: } 19 \\
\text { Ag Day: } 150 \\
\text { Halloween Quest: } 25 \\
\text { Pop Up: } 28 \\
\text { Total: } 222 \text { given away at promotional } \\
\text { events }\end{array}$ \\
\hline
\end{tabular}

Overall swag inventory 